\title{
3-Mercaptopropyltrimethoxysilane Modified Diatomite: Preparation and Application for Voltammetric Determination of Lead (II) and Cadmium (II)
}

\author{
Dinh Quang Khieu, ${ }^{1}$ Bui Hai Dang Son, ${ }^{1}$ Vo Thi Thanh Chau, ${ }^{2}$ Pham Dinh Du, ${ }^{3}$ \\ Nguyen Hai Phong, ${ }^{1}$ and Nguyen Thi Diem Chau ${ }^{4}$ \\ ${ }^{1}$ College of Science, Hue University, Hue City 530000, Vietnam \\ ${ }^{2}$ Faculty of Technology, Industrial University of Ho Chi Minh City, Quang Ngai Campus, Quang Ngai City 570000, Vietnam \\ ${ }^{3}$ Faculty of Natural Science, Thu Dau Mot University, Thu Dau Mot City 590000, Vietnam \\ ${ }^{4}$ Department of Agriculture and Rural Development, Tam Ky City, Quang Nam Province 560000, Vietnam
}

Correspondence should be addressed to Dinh Quang Khieu; dqkhieu@hueuni.edu.vn

Received 11 September 2016; Revised 15 January 2017; Accepted 15 February 2017; Published 14 March 2017

Academic Editor: Pedro Ávila-Pérez

Copyright (C) 2017 Dinh Quang Khieu et al. This is an open access article distributed under the Creative Commons Attribution License, which permits unrestricted use, distribution, and reproduction in any medium, provided the original work is properly cited.

\begin{abstract}
In this study, functionalized diatomite was prepared by grafting of 3-mercaptopropyltrimethoxysilane (MPTMS) to diatomite (MPTMS-diatomite). The diatomite with thermal treatment from 100 to $700^{\circ} \mathrm{C}$ was functionalized by MPTMS under dry and humid conditions. The obtained MPTMS-diatomite was characterized by X-ray diffraction (XRD), thermal gravity-differential scanning calorimeter (TG-DSC), and Fourier transformation infrared (FT-IR). The results showed that an increase in treatment temperature seems to reduce the loading of MPTMS onto diatomite. The humidity of diatomite was favorable for the grafting of functional groups on the surface. The possible mechanisms of MPTMS loading to diatomite (MPTMS-diatomite) were also proposed. The performance of a carbon paste electrode (CPE) modified with MPTMS-diatomite in the simultaneous determination of Cd(II) and $\mathrm{Pb}(\mathrm{II})$ ions was addressed.
\end{abstract}

\section{Introduction}

Heavy metals ( $\mathrm{Hg}(\mathrm{II}), \mathrm{Pb}(\mathrm{II}), \mathrm{Cd}(\mathrm{II}), \mathrm{Cu}(\mathrm{II}), \mathrm{Co}(\mathrm{II}), \mathrm{Ni}(\mathrm{II})$, $\mathrm{Zn}(\mathrm{II})$, etc.), which are commonly found in wastewaters discharged from chemical manufacturing, mining, extractive metallurgy, nuclear, and other industries, cause danger to humans and aquatic animals and plants and therefore must be controlled urgently [1]. The detection of heavy metal ions in water samples has received much attention over the past few years. The commonly used methods for metal analysis are atomic absorption spectrometry (AAS) and electrothermal atomic absorption spectrometry (ETAAS), inductively coupled plasma-mass spectrometry (ICP-MS), inductively coupled plasma atomic emission spectrometry (ICP-AES), and inductively coupled plasma optical emission spectrometry (ICP-OES) [2-4]. These techniques can assist quantitative analyses of the total amount of toxic metals in water samples. However, disadvantages such as instrument costs and complex operation procedures may limit the use of these techniques.

Anodic stripping voltammetry (ASV) is a useful electrochemical method for detecting trace metals because of its wide linear dynamic range and low detection limit which results from a preconcentration step performed directly in the voltammetric cell. Several porous materials have been utilized as electrode modifiers with the aim of preconcentrating the analyte at the electrode surface via a selective reaction due to special function groups grafted to electrode surface [5-10].

Diatomite, which consists of a wide variety of sized diatoms in a structure containing up to $80-90 \%$ pores, is a pale-coloured, soft, lightweight sedimentary rock composed principally of silica fossils of aquatic unicellular alga [11]. Diatomite has received considerable attention for its unique combination of physical and chemical properties including 
TABLE 1: Chemical composition of diatomite (wt.\%).

\begin{tabular}{lcccccc}
\hline Elements & $\mathrm{K}$ & $\mathrm{Al}$ & $\mathrm{Si}$ & $\mathrm{Ti}$ & $\mathrm{Fe}$ & Others \\
Raw diatomite & 0.34 & 13.07 & 76.02 & 1.31 & 7.68 & 1.58 \\
\hline
\end{tabular}

large porosity, fine particle size, and chemical inertness [12]. Silanol groups often occur on the diatomite surface especially on the natural diatomite surface. The density of the silanol groups can be controlled by hydrating diatomite. When these silanol groups combine with organosilane through a series of chemical reaction, the functional groups at the terminal end of the organosilanes can be anchored to the surface of the diatomite to form surface activated products. The diatomite in combination with surface coated functional groups offers a potential materials for adsorption $[13,14]$ and modifying electrodes to determine the dye [13]. Recently, the usage of silicabased materials (especially organically modified silicates) for modifying glassy carbon electrodes (GCEs) applied to the voltammetric detection of metal ions such as $\mathrm{Hg}(\mathrm{II}), \mathrm{Cd}(\mathrm{II})$, and $\mathrm{Pb}(\mathrm{II})$ has been extensively reported [6, 7]. However the use of organosilane modified diatomite as an electrode modifier less pronounced so far [15]. To the best of our knowledge, the use of a 3-mercaptopropyltrimethoxysilane (MPTMS) which grafted diatomite for modifying electrode in connection with the electrochemical analysis of $\mathrm{Pb}$ (II) and $\mathrm{Cd}$ (II) has not yet been reported.

In this paper, the preparation of MPTMS modified diatomite was demonstrated. The effects of thermal treatment of diatomite and the humidity of diatomite on MPTMS functionalization and the possible proposed mechanisms of MPTMS grafting diatomite surface were discussed. The MPTMS-diatomite which was used to modify electrode for simultaneous determination of $\mathrm{Pb}(\mathrm{II})$ and $\mathrm{Cd}(\mathrm{II})$ in aqueous solution by differential pulse anodic stripping voltammetry method (DP-ASV) was also studied.

\section{Experimental}

2.1. Materials. Diatomite sample was collected from $\mathrm{Phu}$ Yen province, Vietnam, after removing organic stuff by repeated sedimentation and desiccation at $100^{\circ} \mathrm{C}$. The 3mercaptopropyltrimethoxysilane (MPTMS, >99\%, Merck) and chloroform (Merck) were used as functional reagent and solvent, respectively. The chemical composition of diatomite analyzed by EDS was listed in Table 1.

All working solutions of reagents were prepared from chemicals for analysis (Merck, Germany). Acetate buffer solutions (ABS) of $\mathrm{pH}=4,5$ were prepared from $\mathrm{CH}_{3} \mathrm{COOH}$ and $\mathrm{CH}_{3} \mathrm{COONa}$ (Merck). $\mathrm{pH}$ of the ABS was adjusted by adding $1.0 \mathrm{M}$ nitric acid or $1.0 \mathrm{M}$ sodium hydroxide solutions into the $\mathrm{ABS}$ and then checking by $\mathrm{pH}$ meter. Working solution of $\mathrm{Cd}(\mathrm{II})$ and $\mathrm{Pb}(\mathrm{II})$ was prepared daily from stock solution (1000 ppm, Merck, Germany). Nafion $\left(\mathrm{C}_{7} \mathrm{HF}_{13} \mathrm{O}_{5} \mathrm{~S} \cdot \mathrm{C}_{2} \mathrm{~F}_{4}\right.$, Merck) was used as an adhesive and electric conductivity material.

2.2. The Functionalization of Diatomite with MPTMS (MPTMS-Diatomite). The diatomite was calcinated at 100,
300,500 , and $700^{\circ} \mathrm{C}$ for 3 hours. The incorporation of MPTMS into calcinated diatomite was conducted under dried and humid conditions. For the dry condition, 2 grams of calcinated diatomite was mixed with $2 \mathrm{~g}$ of MPTMS and $36 \mathrm{~mL}$ of chloroform in a $250 \mathrm{~mL}$ flask covered with watch glass. After mixing the slurry for 4 days at ambient temperature by a magnetic stirrer, it was washed with $10 \mathrm{~mL}$ of chloroform and filtered through a Buchner funnel. The separated solid was dried at $70^{\circ} \mathrm{C}$ for 24 hours. The functionalized diatomite is denoted as $100 \mathrm{D}, 300 \mathrm{D}, 500 \mathrm{D}$, and $700 \mathrm{D}$. The number implies temperature at which diatomite was heat-treated prior to functionalization. For the humid condition, the calcinated diatomite was hydrated for 2 hours in a desiccator containing saturated $\mathrm{NaCl}$ solution at the bottom before functionalization. Two grams of hydrated diatomite was mixed with $2 \mathrm{~g}$ of MPTMS for two hours. The solid was filtered and the extra MPTMS was extracted with chloroform in a Soxhlet until the solution in flask was clear. The resulting samples are denoted as $100 \mathrm{H}, 300 \mathrm{H}, 500 \mathrm{H}$, and $700 \mathrm{H}$. With the aim of studying the applicability of the material MPTMS-diatomite, the use of MPTSE-diatomite as an electrode modifier was performed.

\subsection{Voltammetric Procedure}

2.3.1. Preparation of Working Electrode-Modified Electrode. The preparation procedure was carried out as [16]. In brief, glassy carbon electrode (GCE) was first polished with $0.05 \mu \mathrm{m} \mathrm{Al} \mathrm{O}_{3}$ slurries on a polishing cloth and then rinsed ultrasonically with $2 \mathrm{M} \mathrm{HNO}_{3}$, absolute ethanol, and doubledistilled water. Subsequently, the GCE was electrochemically cleaned by cyclic potential scan between $-1.5 \mathrm{~V}$ and $+1.5 \mathrm{~V}$ in $0.5 \mathrm{M} \mathrm{ABS} \mathrm{pH} 4.5$ with the scan rate of $0.10 \mathrm{~V} \mathrm{~s}^{-1}$. After that, the electrode was rinsed with double-distilled water. Nafion-MPTMS-diatomite composite was prepared by dispersing $5.0 \mathrm{mg}$ MPTMS-diatomite powder into $1.0 \mathrm{~mL}$ Nafion $(0.1 \mathrm{wt} \%)$ and sonicated. The GCE was coated with $5 \mu \mathrm{L}$ of the composite and dried at room temperature $\left(\sim 25^{\circ} \mathrm{C}\right)$ (denoted as MPTMS-diatomite/GCE).

2.3.2. Voltammetric Procedure. Solution under study (final volume of $10 \mathrm{~mL}$ ) containing $0.1 \mathrm{M} \mathrm{ABS}(\mathrm{pH} 4.5)$ and $100 \mathrm{ppb}$ $\mathrm{Cd}(\mathrm{II})$ and $200 \mathrm{ppb} \mathrm{Pb}$ (II) was transferred into the electrochemical cell with the 3 electrodes. Then, voltammetric measurement was conducted as follows:

(i) For surveying voltammetric characteristics of Cd(II) and $\mathrm{Pb}(\mathrm{II})$ on the MPTMS-diatomite/GCE: Cd(II) and $\mathrm{Pb}(\mathrm{II})$ was accumulated on the surface of the modified electrode at a potential of $-1.2 \mathrm{~V}\left(E_{\text {acc }}\right)$ for an accumulated time of $60 \mathrm{~s}\left(t_{\mathrm{acc}}\right)$. During this stage, the electrode was rotated at a constant rate of $1000 \mathrm{rpm}$. After that, the electrode rotation was off. Then, cyclic voltammograms were recorded from $-1.2 \mathrm{~V}$ to $+0.2 \mathrm{~V}$ (forward potential scan) and subsequently from $+0.2 \mathrm{~V}$ to $-1.2 \mathrm{~V}$ (reverse potential scan) at a scan rate of $0.1 \mathrm{~V} \mathrm{~s}^{-1}$.

(ii) For differential pulse anodic stripping voltammetric (DP-ASV) determination of $C d(I I)$ and $P b(I I)$ on 
electrode MPTMS-diatomite/GCE: during the DPASV procedure, the $\mathrm{Cd}(\mathrm{II})$ and $\mathrm{Pb}(\mathrm{II})$ were accumulated on the surface of the rotating modified electrode as done for the above procedure. After that, the electrode rotation was off for $10 \mathrm{~s}$ and then DPASV voltammograms were recorded from $-1.2 \mathrm{~V}$ to $+0.2 \mathrm{~V}$ at a scan rate of $0.02 \mathrm{~V} \mathrm{~s}^{-1}$ and suitable differential voltammetry technique parameters. During the potential anodic scan, $\mathrm{Cd}(0)$ and $\mathrm{Pb}(0)$ on the electrode surface were oxidized to $\mathrm{Cd}(\mathrm{II})$ and $\mathrm{Pb}(\mathrm{II})$. DP-ASV voltammograms of blank solution (without $\mathrm{Cd}(\mathrm{II})$ and $\mathrm{Pb}(\mathrm{II})$ and prepared from double-distilled water) were similarly recorded before each measurement. The $\mathrm{Cd}(\mathrm{II})$ and $\mathrm{Pb}(\mathrm{II})$ quantitation was done by standard addition method.

2.4. Apparatuses. The phases were monitored by powder $\mathrm{X}$-ray diffraction (XRD), recorded on 8D Advance Bucker, Germany with $\mathrm{CuK}_{\alpha}$ radiation in the range of from $20^{\circ}$ to $60^{\circ}$ with a scan step size of $0.01^{\circ}$ and a scan step time of $0.04 \mathrm{~s}$. The amounts of MPTMS incorporated into diatomite were evaluated by TG-DSC SETARAM under ambient atmosphere. Morphology of diatomite was observed by scanning electron microscopy (SEM.Jeole-3432) and transmission electron microscope (TEM) (JEOL JEM-2100F). Fourier transform infrared (FT-IR) spectra of the typical samples (1 wt\% sample + 99 wt $\% \mathrm{KBr}$ ) were collected on Shimadzu FT-IR 8010M; the wavenumber range was $500-4000 \mathrm{~cm}^{-1}$. A CPA-HH5 Computerized Polarographic Analyzer (produced by Laboratory of Computer Application to Chemistry, Institute of Chemistry, Vietnam Academy of Science and Technology) was used for voltammetry experiments. All measurements were done in the cell with three electrodes: a GCE with a diameter of $2.8 \pm 0.1 \mathrm{~mm}$ used for formatting the modified electrode as working electrode, $\mathrm{Ag} / \mathrm{AgCl} / 3 \mathrm{M} \mathrm{KCl}$ as reference electrode, and a platinum wire as auxiliary electrode. All measurements were carried out at room temperature.

\section{Results and Discussion}

3.1. Preparation of MPTMS Modified Diatomite (MPTMSDiatomite). Figure 1 shows XRD patterns of diatomite calcinated at $100^{\circ} \mathrm{C}, 300^{\circ} \mathrm{C}, 500^{\circ} \mathrm{C}$, and $700^{\circ} \mathrm{C}$. The raw diatomite (dried at $100^{\circ} \mathrm{C}$ ) consisted of mainly amorphous structure. At $300^{\circ} \mathrm{C}$, the characterized peak of quartz was observed indicating that the silica in amorphous form was crystallized to form quartz crystallites. The diffraction intensity of quartz phase increases with an increase in calcinated temperature. Figure 2 shows SEM and TEM observation. Morphology of raw diatomite shows a cylindrical structure with a $c a$. length of $10-20 \mu \mathrm{m}$ and an internal pore diameter of about $2-3 \mu \mathrm{m}$. There are nearly regular arrays of submicron pore in a diameter of $c a .100 \mathrm{~nm}$ in the wall.

In order to investigate the surface characteristics of raw and calcined diatomite, FT-IR analyses were carried out in the range $400-4000 \mathrm{~cm}^{-1}$. The main absorption bands for raw diatomite, as shown in Figure 3, were observed at 466, $528,690,798,914,1022,1153,3622$, and $3695 \mathrm{~cm}^{-1}$. The absorption peaks around 466 and $528 \mathrm{~cm}^{-1}$ represent to the

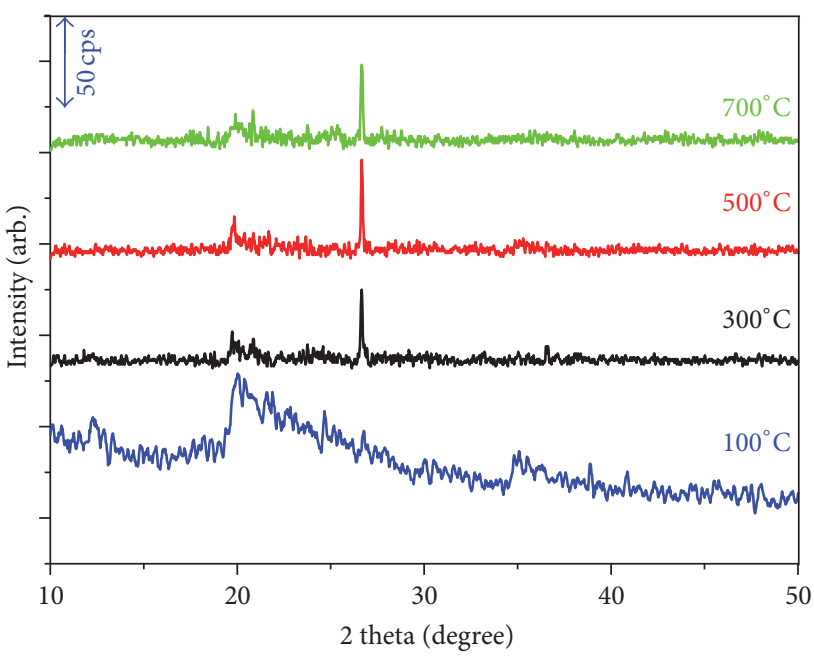

FIGURE 1: XRD patterns of diatomite calcined at different temperatures.

Si-O-Si bending vibration [17]. The 690 and $798 \mathrm{~cm}^{-1}$ bands reflect $\mathrm{SiO}-\mathrm{H}$ vibration while the $910 \mathrm{~cm}^{-1}$ band corresponds to the $\mathrm{Si}-\mathrm{O}$ stretching of silanol group. The bands at 1153 and $1022 \mathrm{~cm}^{-1}$ are strong due to stretching vibration of the siloxane (-Si-O-Si-) groups [18]. The band at $1639 \mathrm{~cm}^{-1}$ corresponds to $\mathrm{H}-\mathrm{O}-\mathrm{H}$ bending vibration of water. The bands at 3695 and 3622 are attributed to the internal silanol due to strongly interacting vicinal $\mathrm{OH}$ [19]. The surface is also predominantly covered by physically adsorbed water in the pore and water bounded to the surface hydroxyl groups via $\mathrm{H}$-bonds $[19,20]$. By removing adsorbed water, upon heating the diatomite at $700^{\circ} \mathrm{C}$, the $\mathrm{OH}$ groups on diatomite surface may be removed. The disappearance of the $\mathrm{OH}$ groups may have a significant effect on MPTMS grafting to diatomite, which is dependent on not only the pore structure of diatomite but also the surface functional groups.

Figure 4 shows DSC and TG diagrams of diatomite functionalized by MPTMS at dried conditions. The DSC and TG curves were similar for all samples. The exothermic peak, together with no any ignition loss at around $300^{\circ} \mathrm{C}$, should be attributed to the crystallization of amorphous silica to quartz. The result also agrees with the fact that the crystallization of quartz was detected at $300^{\circ} \mathrm{C}$ by XRD analysis. However, even for sample $300 \mathrm{D}-700 \mathrm{D}$ which was calcinated at $300^{\circ} \mathrm{C}$ for 3 hours before functionalization, this peak is also observed. This can be explained by a reconstruction to form amorphous silica during silane treatment. The exothermic peaks and ignition losses at around $520^{\circ} \mathrm{C}$ should be assigned to the decomposition and oxidation of MPTMS incorporated into diatomite. The hydrolysis of MPTMS into silanols occurs in water. The silane incorporated into diatomite is due to the condensation of silanols of diatomite and silane. In this work, it is suggested that the silane is strongly bonded to diatomite surface as silane is not removed by washing chloroform, dispersed in water, or heated at $100^{\circ} \mathrm{C}$. Then the amount of MPTMS incorporated into diatomite is proportional to the amount of ignition loss in range $100^{\circ} \mathrm{C}$ to $700^{\circ} \mathrm{C}$ calculated by 


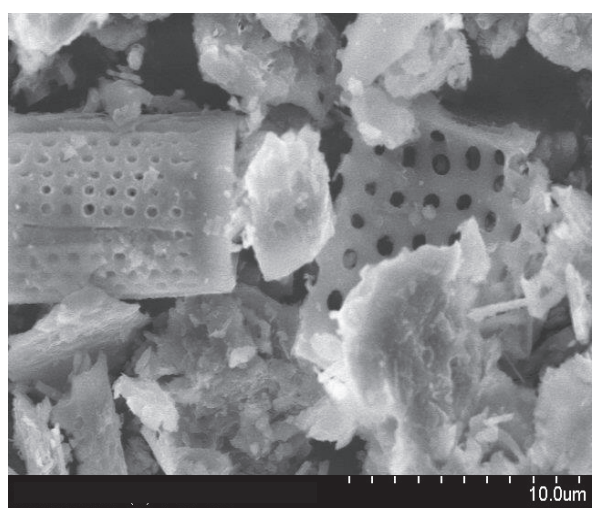

(a)

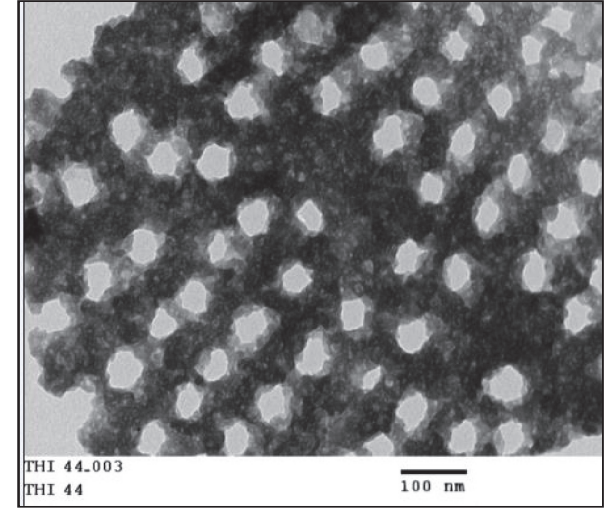

(b)

FIgURE 2: (a) SEM and (b) TEM observation of raw diatomite.

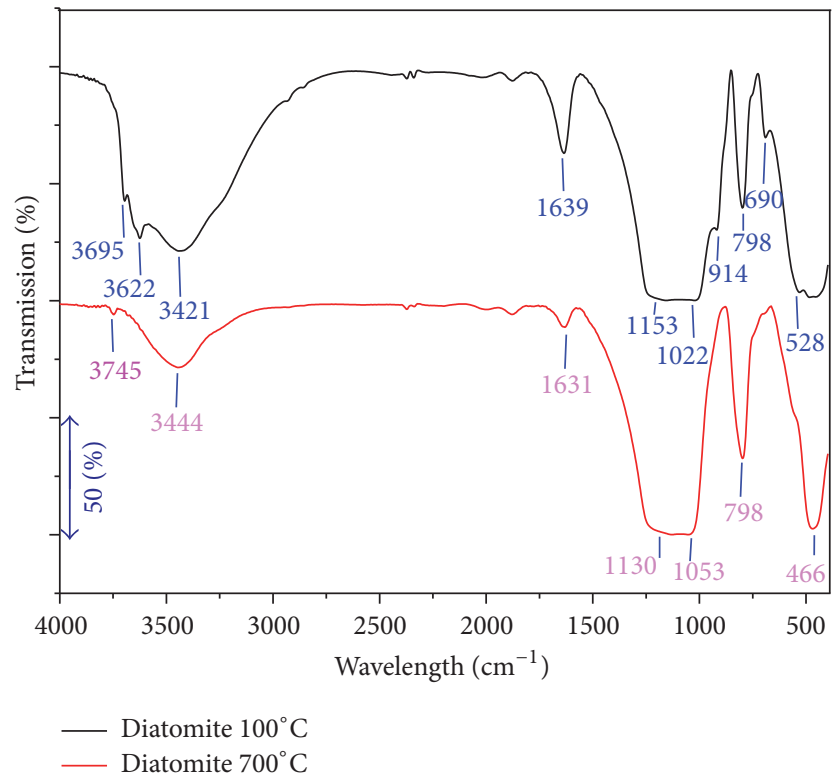

FIGURE 3: Infrared spectra of (a) raw and (b) calcined diatomite at $700^{\circ} \mathrm{C}$.

TG. Therefore, the ignition loss $\left(100-700^{\circ} \mathrm{C}\right)$ was assumed as MPTMS loading to diatomite. The amount of MPTMS seems to increase slightly from $5.6 \%$ to $6.3 \%$ for D100 and D300 and decrease remarkably with a further increase in thermal treatment temperature (see Table 2).

Figure 5 shows TG-DSC diagrams of functionalized diatomite under humid conditions. The curves were similar to all samples. The thermal behaviors were also similar to the case of samples under dried conditions except for ignition loss together exothermic peaks at around $300^{\circ} \mathrm{C}$ observed for most cases. From Table 2, the amount of MPTMS incorporated into diatomite seems to be higher in the samples in dried conditions and the diatomite thermal treated at $100^{\circ} \mathrm{C}-300^{\circ} \mathrm{C}$ is most favorable for MPTMS functionalization.
There are two types of silanols, isolated and H-bonded silanols on diatomite surface [20]. At room temperature, both types of silanols are $\mathrm{H}$-bonded with water. With an increase in temperature, dehydration occurs. At first, the desorption of water and the exposure of more and more isolated silanols were favorable for the silanols of silane adsorbing onto diatomite surfaces. This accounts for the fact that the high amount of MPTMS was incorporated into diatomite calcinated in the range of $100-300^{\circ} \mathrm{C}$. The calcinated diatomite exposed to water-saturated medium could create more silanols, which consequently adsorb MPTMS more strongly than the diatomite under dried conditions. As the temperature increases to more than $300^{\circ} \mathrm{C}$, the silanols begin to condense to form siloxane bridges that are not favorable for coupling reactions. In the case of hydrated diatomite, two decompositions of silane incorporated into diatomite are observed at around $320^{\circ} \mathrm{C}$ and $520^{\circ} \mathrm{C}$ in TGDSC curves instead of only $520^{\circ} \mathrm{C}$ in the case of the dried diatomite. Based on the results reported by Johansson et al. [21] about adsorption of silane coupling agents onto kaolin surfaces, we suggest two possible mechanisms by which MPTMS react with diatomite surface. The first proposed mechanism involves four steps:

(1) MPTMS was converted to the reactive silanol formed by hydrolysis

$$
\begin{gathered}
\text { SH- }\left(\mathrm{CH}_{2}\right)_{3} \mathrm{Si}\left(\mathrm{OCH}_{3}\right)_{3}+3 \mathrm{H}_{2} \mathrm{O} \Longleftrightarrow \\
\mathrm{SH}-\left(\mathrm{CH}_{2}\right)_{3} \mathrm{Si}(\mathrm{OH})_{3}+3 \mathrm{HOCH}_{3}
\end{gathered}
$$

(2) Condensation of the organosilane to oligomers is presented:

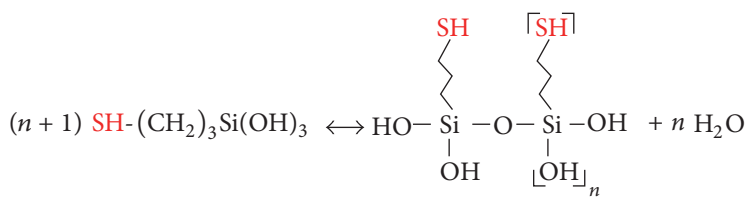


TABLE 2: The amount of MPTES incorporated into diatomite estimated by TG.

\begin{tabular}{|c|c|c|c|c|c|c|c|c|}
\hline & \multicolumn{4}{|c|}{ Dried condition } & \multicolumn{4}{|c|}{ Humid condition } \\
\hline & $100 \mathrm{D}$ & $300 \mathrm{D}$ & $500 \mathrm{D}$ & $700 \mathrm{D}$ & $100 \mathrm{H}$ & $300 \mathrm{H}$ & $500 \mathrm{H}$ & $700 \mathrm{H}$ \\
\hline Ignition loss at $c a .100^{\circ} \mathrm{C}(\%)$ & 5.67 & 0.00 & 0.00 & 0.00 & 3.71 & 2.45 & 0 & 0.00 \\
\hline Ignition loss at $c a .300^{\circ} \mathrm{C}(\%)$ & 0.00 & 0.00 & 0.00 & 0.00 & 0.00 & 2.02 & 1.31 & 0.80 \\
\hline Ignition loss at $c a .520^{\circ} \mathrm{C} \mathrm{( \% )}$ & 5.44 & 3.76 & 2.55 & 1.82 & 6.99 & 5.69 & 1.70 & 0.97 \\
\hline Total ignition loss $>100^{\circ} \mathrm{C}(\%)$ & 5.44 & 3.76 & 2.55 & 1.82 & 6.99 & 7.71 & 3.01 & 1.77 \\
\hline
\end{tabular}

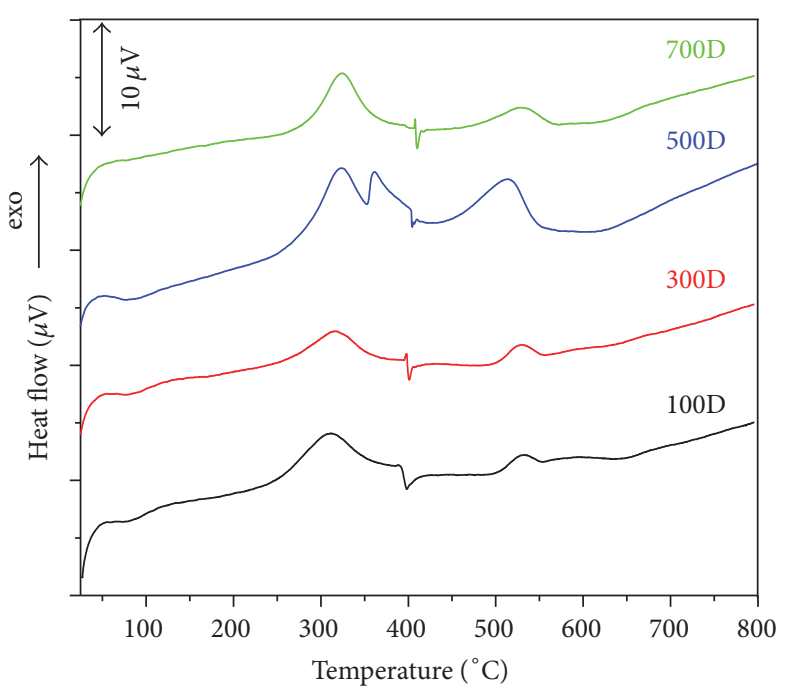

(a)

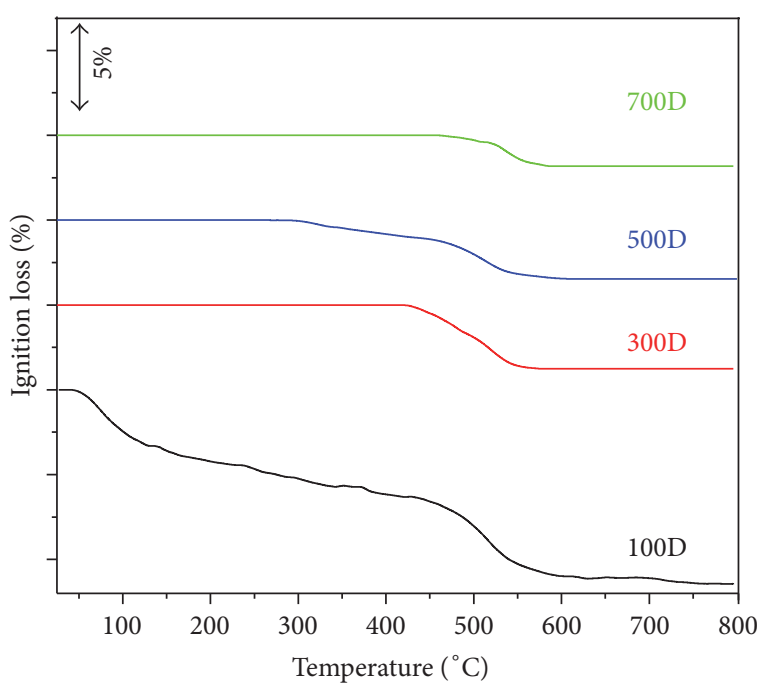

(b)

FIGURE 4: (a) DSC diagrams; (b) TG diagrams of diatomite functionalized by MPTMS at dried condition.

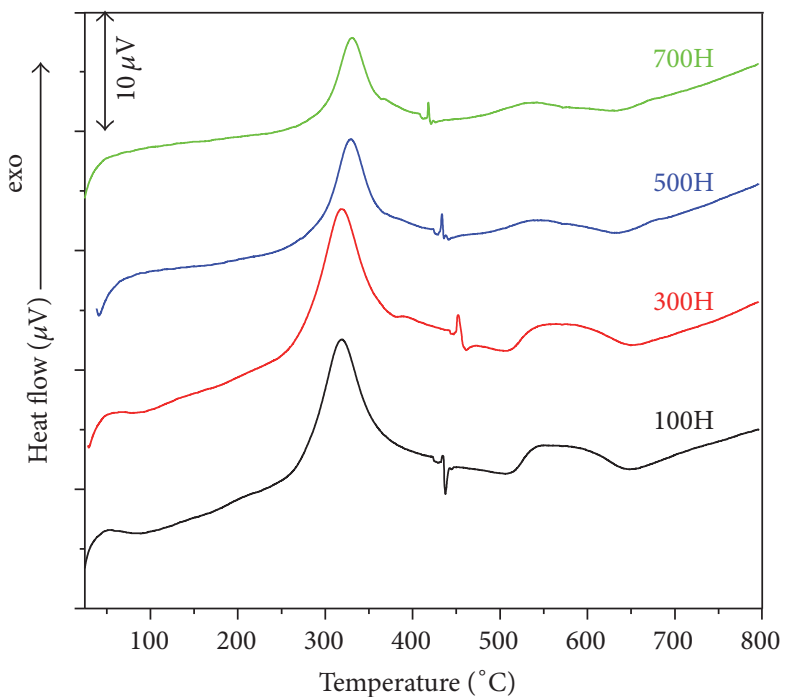

(a)

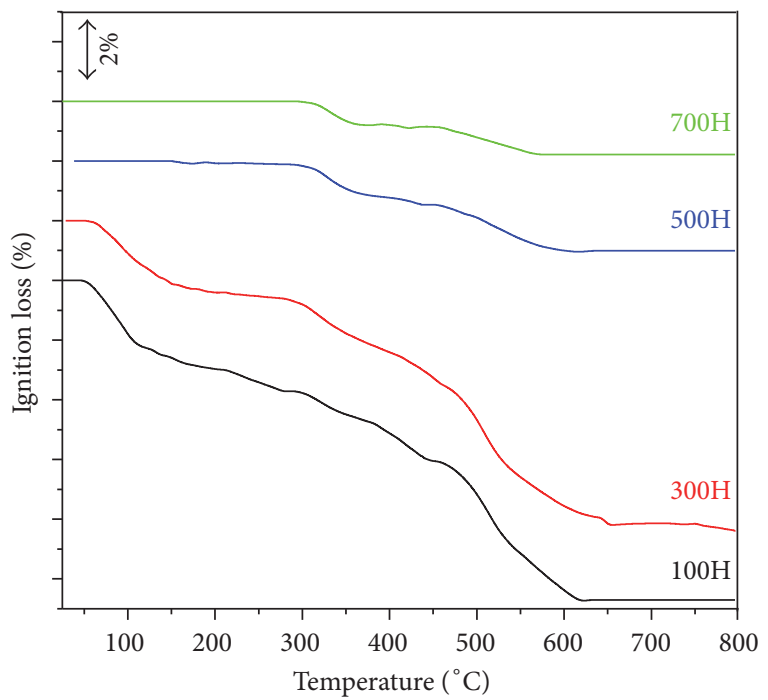

(b)

FIGURE 5: (a) DSC diagrams; (b) TG diagrams of functionalized diatomite under humid conditions. 
(3) Formation of hydrogen bonds between the oligomers and the $\mathrm{OH}$ groups on the diatomite surface is presented:<smiles>C#CC[Si](O)(CCS)O[SiH2]O[SiH](O)O[C@@H](O)OC#C</smiles>

(4) Finally, a covalent linkage is formed under drying

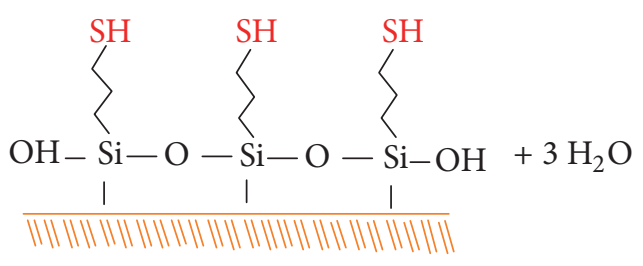

The second proposed mechanism involves only two steps:

(1) MPTMS is converted to the reactive silanol form by hydrolysis ( $\left.\mathrm{R}: \mathrm{CH}_{2}-\mathrm{CH}_{2}-\mathrm{CH}_{2}-\mathrm{SH} ; \mathrm{X}: \mathrm{OCH}_{3}\right)$

$$
\begin{gathered}
\mathrm{SH}-\left(\mathrm{CH}_{2}\right)_{3} \mathrm{Si}\left(\mathrm{OCH}_{3}\right)_{3}+3 \mathrm{H}_{2} \mathrm{O} \Longleftarrow \\
\mathrm{SH}-\left(\mathrm{CH}_{2}\right)_{3} \mathrm{Si}(\mathrm{OH})_{3}+3 \mathrm{HOCH}_{3}
\end{gathered}
$$

(2) The silanol groups react directly with hydroxyl groups on the diatomite surface

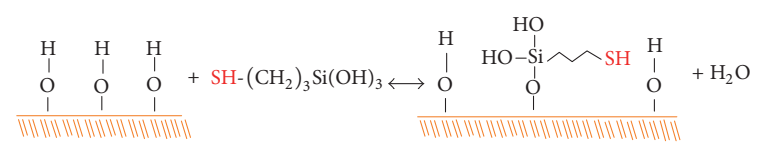

It is assumed that silane incorporated in diatomite by the first mechanism is more stable than one by the second mechanism. It means that it will be decomposed at higher temperature with the silane incorporated by the latter. For silane treatment with dried diatomite, the only ignition loss and exothermic peak at around $520^{\circ} \mathrm{C}$ could be assigned to the decomposition of silane grafting through the first mechanism. When diatomite is hydrated before silane treatment, the incorporation of MPTMS might occur through both mechanisms. Then, ignition loss and exothermic peak at around $300^{\circ} \mathrm{C}$ in TG-DSC for $100-700 \mathrm{H}$ might be assigned to decomposition of silanes in which MPTMS is grafted through the second mechanism.

The effect of hydrated times on the loading of MPTMS was also investigated. The diatomite calcined at $100^{\circ} \mathrm{C}$ for 3 hours was hydrated in a desiccators containing saturated $\mathrm{NaCl}$ solution for $0,1,2,3,6,8$, and $10 \mathrm{~h}$. The functionalization was conducted as in the case of humid conditions. The
TABLE 3: The total amount of ignition loss of MPTMS-diatomite in the range $100^{\circ} \mathrm{C}-700^{\circ} \mathrm{C}$.

\begin{tabular}{lccccccc}
\hline Hydrated time & $0 \mathrm{~h}$ & $1 \mathrm{~h}$ & $2 \mathrm{~h}$ & $3 \mathrm{~h}$ & $6 \mathrm{~h}$ & $8 \mathrm{~h}$ & $10 \mathrm{~h}$ \\
Ignition loss (\%) & 6.99 & 7.21 & 7.91 & 9.88 & 8.04 & 8.90 & 6.59 \\
\hline
\end{tabular}

amount of MPTMS incorporated into diatomite estimated from TG analysis was listed in Table 3.

As can be seen, the amount of MPTMS peaked around 3 hours and then decreased as the time of hydrate was prolonged. Those results provide further evidence that water moisture favors the coupling reaction of silanols of silane and diatomite. However, the hydrated time prolonged means that there was too much water in the channel of diatomite, and the silane molecules will be significantly hydrated and condense each other instead of being bound to the wall and be removed under chloroform reflux condition; that is, the loading amount will decrease. Figure 7 shows TEM and SEM observation of MPTMS modified diatomite. The inclusions were highly dispersed on the diatomite surface (Figure 6(a)). However, pores in diatomite surface around 40-50 nm were also observed by TEM (Figure 6(b)). This means that the MPTMS-diatomite is combining highly porous structure with the binding properties of the thiol groups, leading to a high number of reactive sites that are readily accessible for the target analyte $(\mathrm{Pb}(\mathrm{II})$ and $\mathrm{Cd}(\mathrm{II}))$.

3.2. Voltammetric Characteristics of $C d(I I)$ and $P b(I I)$ on MPTMS-Diatomite/GCE and Limit of Detection (LOD). Figure 7 shows anodic voltammetric curves using electrodes modified by MPTMS-diatomite containing different MPTMS amounts. The percentage number in parenthesis presents the ignition loss which is assigned to as MPTMS amount. $\mathrm{Cd}(\mathrm{II})$ and $\mathrm{Pb}(\mathrm{II})$ ion showed anodic peaks at approximate -0.806 and $-0.584 \mathrm{~V}$ in $0.1 \mathrm{M}$ ABS ( $\mathrm{pH} 4.5$ ), respectively. For bare GCE and Nafion/GCE the broad oxidation peaks were observed. The intensity of anodic peak increases with an increase in MPTMS amount from $6.59 \%$ to $9.88 \%$. A well-defined oxidation peak and high current response were observed using the MPTMS (9.88\%)-diatomite electrode with highest MPTMS amount. Then, the MPTMS-diatomite with the highest amount of incorporated MPTMS was selected for modifying electrodes.

$\mathrm{K}_{3}\left[\mathrm{Fe}(\mathrm{CN})_{6}\right] / \mathrm{K}_{4}\left[\mathrm{Fe}(\mathrm{CN})_{6}\right]$ was selected as a probe to evaluate the performance of the prepared electrodes by cyclic voltammetry. Figure 8 presents the electrochemical responses of bare GCE and MPTMS-diatomite/GCE in $1.0 \mathrm{mM} \mathrm{K}_{3} \mathrm{Fe}(\mathrm{CN})_{6} / \mathrm{K}_{4} \mathrm{Fe}(\mathrm{CN})_{6}\left(10^{-3} \mathrm{M}\right.$ and $\left.0.1 \mathrm{M} \mathrm{KCl}\right)$ solution. It is clear that the cathodic-anodic curves using electrode modified by MPTMS-diatomite were broad compared to that of bare GCE, indicating that the electron-transfer kinetics of $\mathrm{Fe}(\mathrm{CN})_{6}{ }^{3-} / \mathrm{Fe}(\mathrm{CN})_{6}{ }^{4-}$ are gradually prevented, which is probably related to the higher ohmic drop value in the electrode process [22].

The redox behavior of $\mathrm{Cd}(\mathrm{II})$ and $\mathrm{Pb}(\mathrm{II})$ was investigated by cyclic voltammetry in a potential range from -1.2 to $+0.2 \mathrm{~V}$ as shown in Figure 9. The $\mathrm{Cd}(\mathrm{II})$ and $\mathrm{Pb}(\mathrm{II})$ 


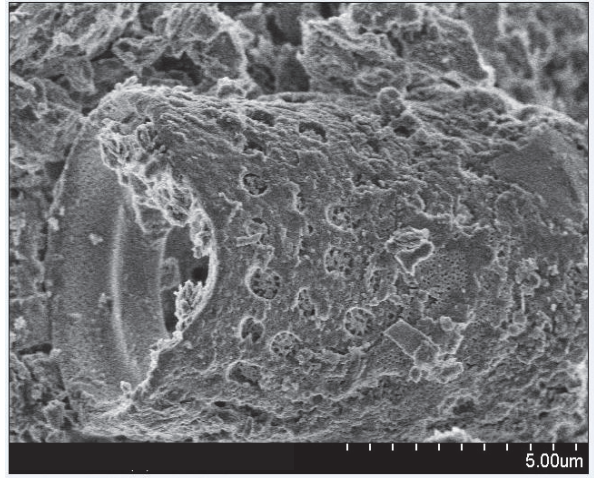

(a)

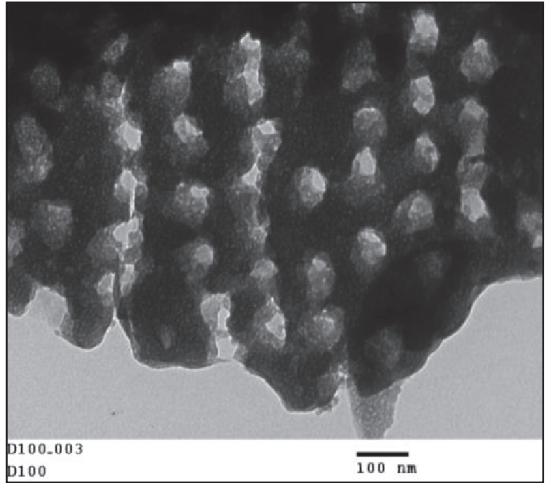

(b)

FIGURE 6: SEM (a) and (b) TEM observation of diatomite modify MPTMS.

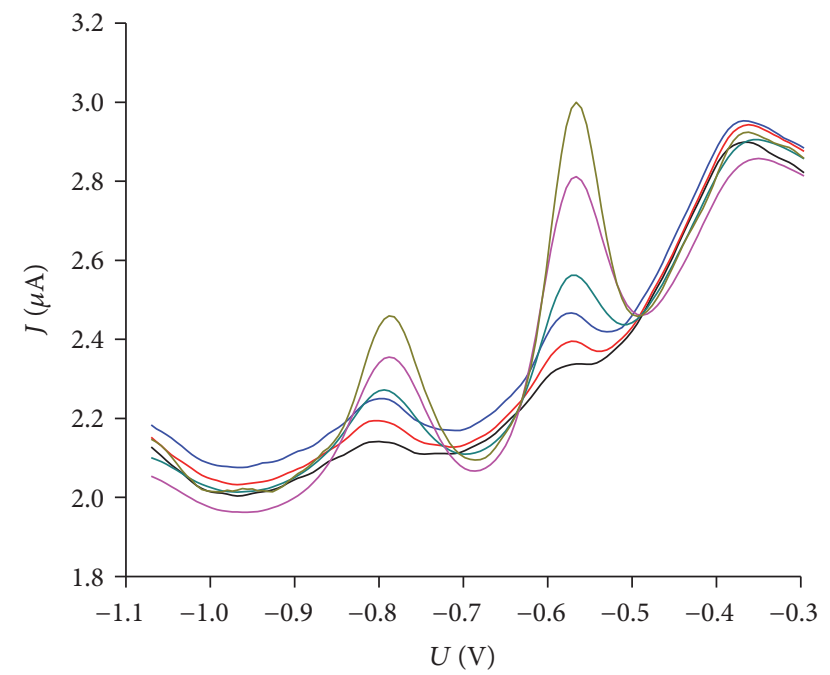

$\begin{aligned} \text { (a) } & -(\mathrm{d}) \\ \text { (b) } & -(\mathrm{e}) \\ \text { (c) } & -(\mathrm{f})\end{aligned}$

Figure 7: DP-ASV voltammograms for $\mathrm{Cd}(\mathrm{II})$ and $\mathrm{Pb}(\mathrm{II})$ using GCE modified by MPTMS-diatomite with differential amounts. (a) Bare GCE; (b) Nafion/GCE; (c) MPTMS (6.99\%)-diatomite/GCE; (d) MPTMS (7.21\%)-diatomite/GCE; (e) MPTMS (8.04\%)diatomite/GCE; (f) MPTMS (9.88\%)-diatomite/GCE recorded in $0.1 \mathrm{M}$ ABS (pH 4.5) containing 100 ppb Cd(II) and 200 pbb $\mathrm{Pb}(\mathrm{II})$; scan rate $0.10 \mathrm{~V} \mathrm{~s}^{-1}$

anodic and cathodic peaks were observed for the diatomiteMPTMS/GCE; the peak separation of anodic and cathodic potentials for $\mathrm{Cd}(\mathrm{II})$ and $\mathrm{Pb}(\mathrm{II})$ were $0.226 \mathrm{~V}$ and $0.139 \mathrm{~V}$, respectively. Therefore, the electrochemical process of Cd(II) and $\mathrm{Pb}(\mathrm{II})$ on the electrode surfaces was quasi-reversible. The analytical signals for electrode surface were stable for at least 5 measuring cycles with the relative standard deviation (RSD) from 2.75 to $3.5 \%$. These results indicated very good reproducibility for $\mathrm{Cd}(\mathrm{II})$ and $\mathrm{Pb}$ (II) detection with the developed electrode. The anodic peak current of $\mathrm{Cd}(\mathrm{II})$ and $\mathrm{Pb}(\mathrm{II})\left(I_{\mathrm{P}}\right)$ was higher than the cathodic peak current, $c a$.

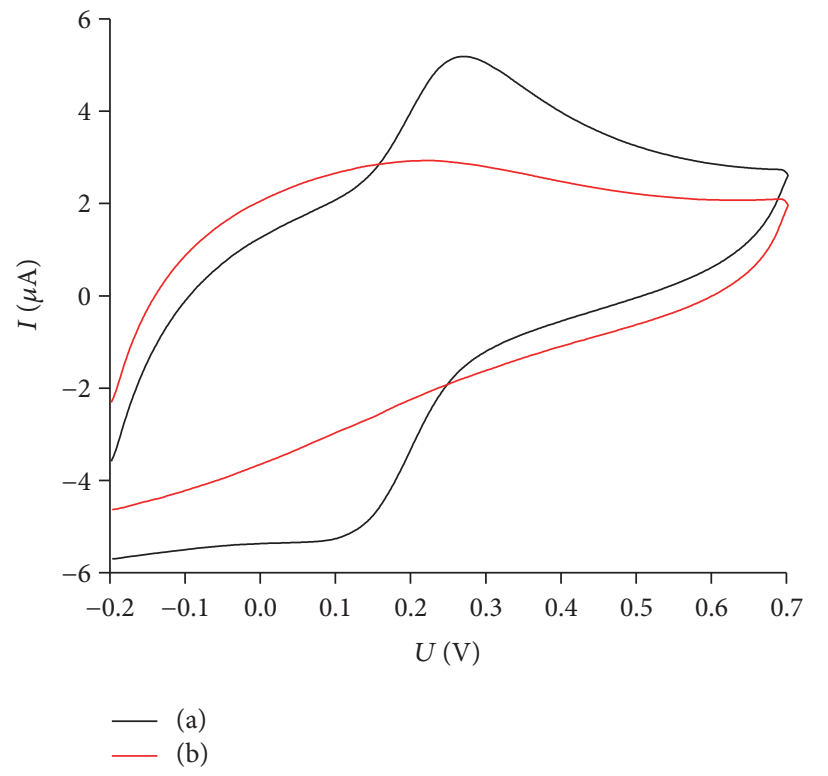

Figure 8: Cyclic voltammetric curves recorded in $10^{-3} \mathrm{M}$ $\mathrm{K}_{3}\left[\mathrm{Fe}(\mathrm{CN})_{6}\right] / \mathrm{K}_{4}\left[\mathrm{Fe}(\mathrm{CN})_{6}\right]$ solutions containing $0.1 \mathrm{M} \mathrm{KCl}$; scan rate $0.10 \mathrm{~V} \mathrm{~s}^{-1}$. (a) GCE; (b) diatomite-MPTMS/GCE.

1.5-fold and 16.5-fold, respectively. It means that the anodic curves can be used for analytical signals.

The thiol group binds $\mathrm{Cd}(\mathrm{II})$ and $\mathrm{Pb}(\mathrm{II})$ to surface complexes because of its high affinity to metal ions. The metals were accumulated in electrode due to reduction reaction and then dissolved in solution through oxidation reaction. The electrochemical reaction occurred as follows [23, 24]:

$$
\begin{aligned}
(\equiv \mathrm{SH})_{2}+\mathrm{M}(\mathrm{Cd}(\mathrm{II}) \text { or } \mathrm{Pb}(\mathrm{II})) \longleftrightarrow & \mathrm{SM}+2 \mathrm{H}^{+} \\
& \text {Complex step } \\
& \equiv \mathrm{SM}+2 \mathrm{e} \longleftrightarrow \equiv \mathrm{SM}^{0} \quad \text { Accumulation step } \\
& \equiv \mathrm{SM}^{0}-2 e+2 \mathrm{H}^{+} \longleftrightarrow(\equiv \mathrm{SH})_{2}+2 \mathrm{M}(\mathrm{II})
\end{aligned}
$$




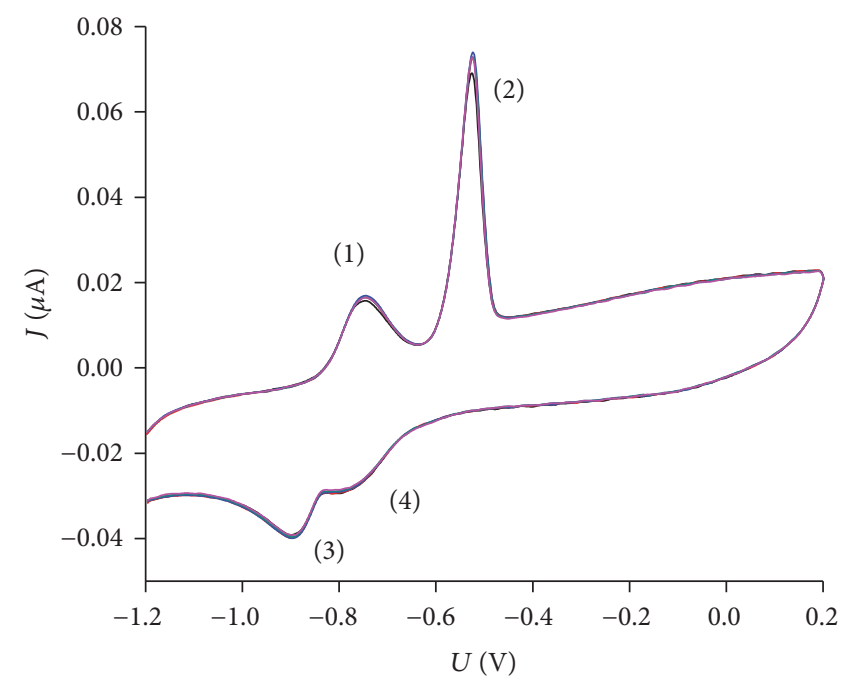

FIGURE 9: Cyclic voltammetric curves recorded in $0.1 \mathrm{M}$ ABS (pH 4.5) containing $100 \mathrm{ppb} \mathrm{Cd}(\mathrm{II})$ and $200 \mathrm{pbb} \mathrm{Pb}$ (II); scan rate $0.10 \mathrm{~V} \mathrm{~s}{ }^{-1}$. (1): $I_{\mathrm{a}, \mathrm{Cd}}=0.0152 \mathrm{~mA}, \mathrm{RSD}=2.75 \%(n=5)$, and $E_{\mathrm{a}, \mathrm{Cd}}=-0.751 \mathrm{mV} .(2): I_{\mathrm{a}, \mathrm{Pb}}=0.0627 \mathrm{~mA}, \mathrm{RSD}=2.83 \%(n=5)$, and $E_{\mathrm{a}, \mathrm{Pb}}=-0.525 \mathrm{mV} .(3): I_{\mathrm{c}, \mathrm{Cd}}$ $=0.0102 \mathrm{~mA}, \mathrm{RSD}=3.50 \%(n=5)$, and $E_{\mathrm{c}, \mathrm{Cd}}=-0.897 \mathrm{mV}$. (4): $I_{\mathrm{c}, \mathrm{Pb}}=0.0038 \mathrm{~mA}, \mathrm{RSD}=2.96 \%(n=5)$, and $E_{\mathrm{c}, \mathrm{Pb}}=-0.758 \mathrm{mV}$.

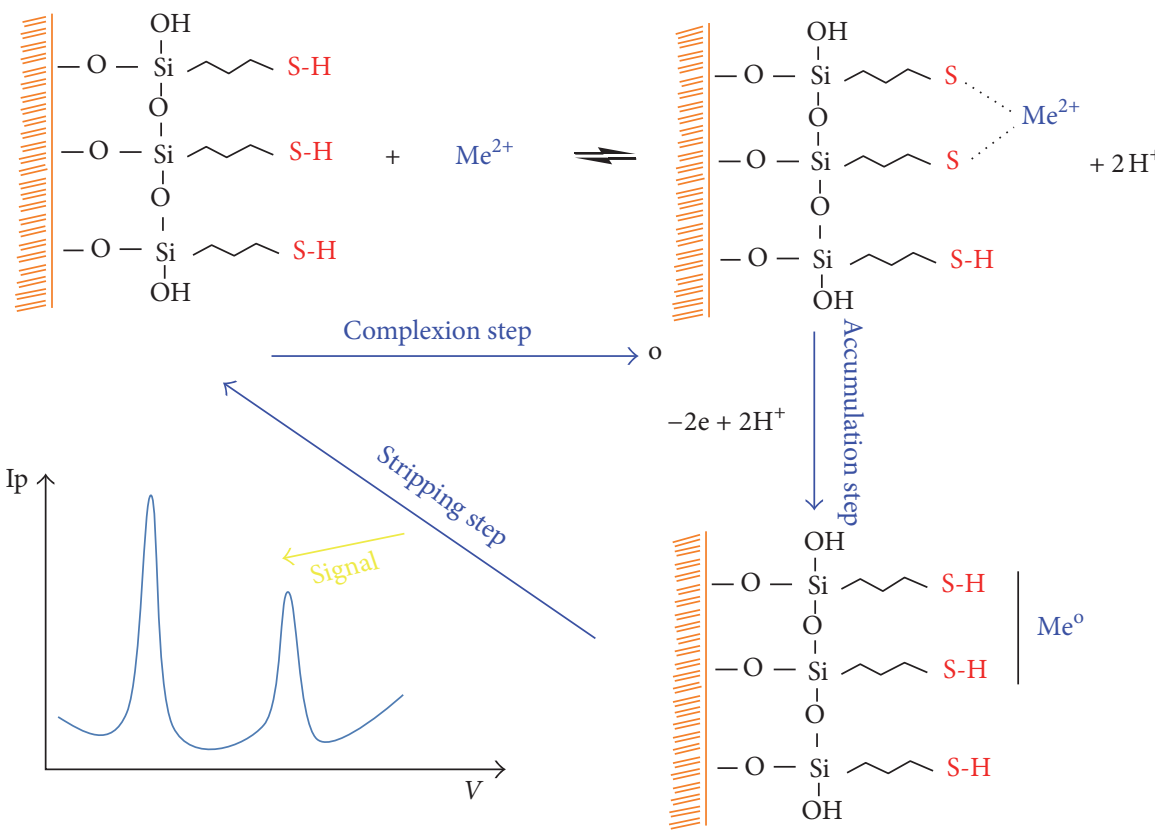

FIGURE 10: Proposed representation of preconcentration and stripping mechanism of $\mathrm{Cd}(\mathrm{II})$ and $\mathrm{Pb}(\mathrm{II})$ on MPTMS-diatomite/GCE.

Electrochemical process of $\mathrm{Pb}(\mathrm{II})$ and $\mathrm{Cd}(\mathrm{II})$ on electrodes modified by MPTMS-diatomite was illustrated by Figure 10.

Figure 11 shows the DP-ASV of $\mathrm{Cd}(\mathrm{II})$ and $\mathrm{Pb}(\mathrm{II})$ with different concentrations. An obvious anodic peaks were observed at around -0.82 and $-0.61 \mathrm{~V}$. These observations can be attributed to the oxidation species of $\mathrm{Cd}(\mathrm{II})$ and $\mathrm{Pb}$ (II), respectively, which have been deposited into the surface of MPTMS-diatomite/GCE during reduction processes. The intensity of anodic peak increased with an increase in Cd(II) and $\mathrm{Pb}$ (II) concentration from 20 to $300 \mathrm{ppb}$. A calibration plot of the anodic current response versus Cd(II) concentration and $\mathrm{Pb}(\mathrm{II})$ is presented in the insets of Figure 11. The results show that the current peak response was linear to the Cd(II) concentration with a $R^{2}$ of 0.999 in the range of 20-300 ppb and the $\mathrm{Pb}(\mathrm{II})$ concentration with $R^{2}$ of 0.994 in the range of $20-150 \mathrm{ppb}$. The limit of detection (LOD) was calculated on the basis of $\left(3.3 S_{a} / b\right)$ criteria $\left(S_{a}\right.$ represents the standard deviation of the intercept while $b$ represents the slope of the calibration curve defined for the LOD concentration range (20-300 ppb)). The LOD for Cd(II) and $\mathrm{Pb}$ (II) calculated was $15.9 \mathrm{ppb}$ and $6.9 \mathrm{ppb}$, respectively.

Table 4 shows a comparison of MPTMS-diatomite-GCE developed with other GCEs modified with other nanoparticles for simultaneous determination of $\mathrm{Pb}(\mathrm{II})$ and $\mathrm{Cd}(\mathrm{II})$. As 


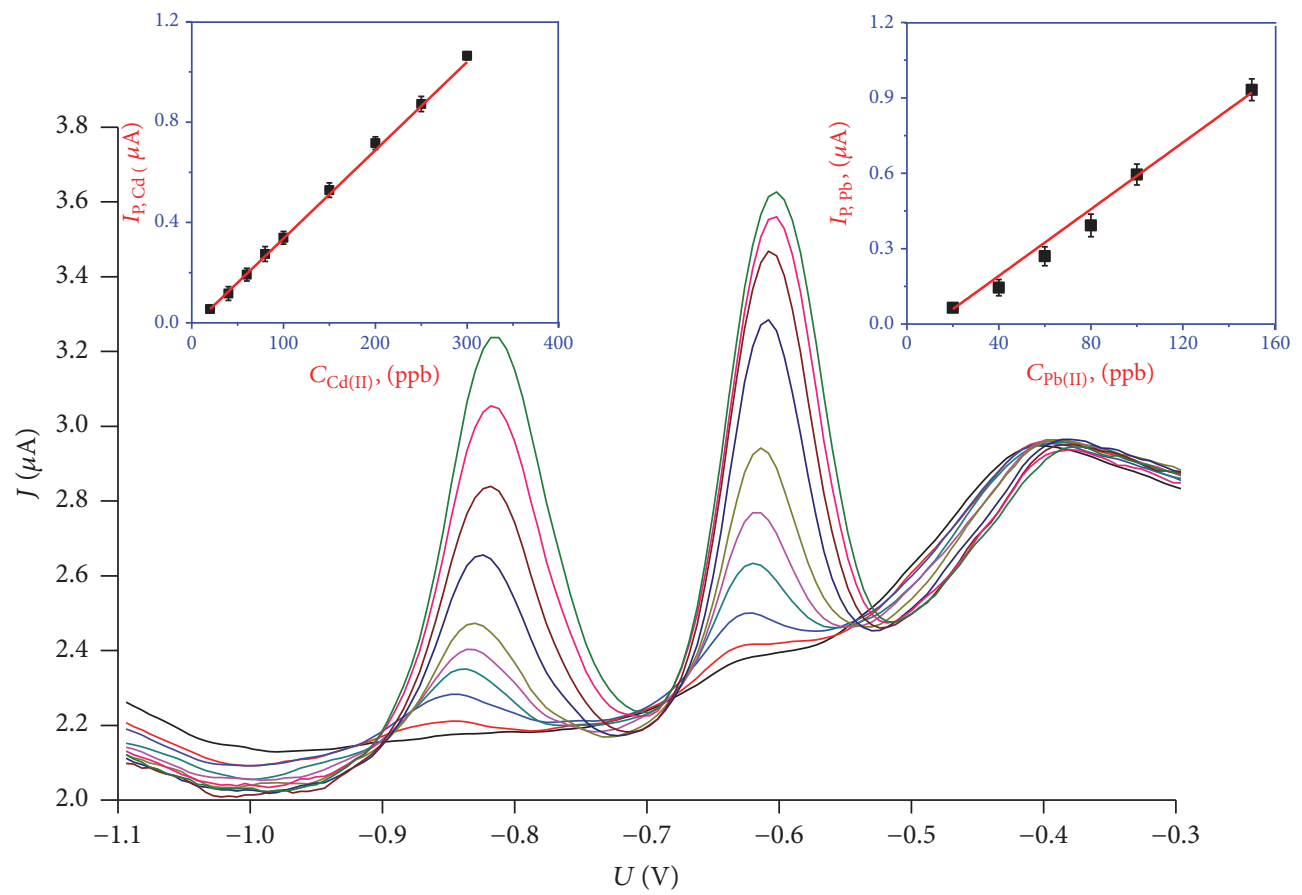

FIGURE 11: The DP-ASV voltammograms of Cd(II) and Pb(II). Conditions: the concentrations in the range of 20 to $300 \mathrm{ppb}$ of the Cd(II) and $\mathrm{Pb}(\mathrm{II})$; other conditions: $0.1 \mathrm{M} \mathrm{ABS}(\mathrm{pH} 4.5) ; E_{\mathrm{acc}}=-1.2 \mathrm{~V} ; t_{\mathrm{acc}}=60 \mathrm{~s}$; pulse amplitude $(\Delta E)=50 \mathrm{mV}$; pulse time $=40 \mathrm{~ms}$; potential step = $6 \mathrm{mV} ; v=20 \mathrm{mV} \mathrm{s}^{-1} ; \omega=2000 \mathrm{rpm}$ (inset (left): a plot of stripping peak current with concentration of Cd(II); inset (right): a plot of stripping peak current with concentration of $\mathrm{Pb}(\mathrm{II}))$.

TABLE 4: Comparison of GCE modified with MPTMS-diatomite with other GCEs modified with other nanoparticles.

\begin{tabular}{|c|c|c|c|c|}
\hline Electrode & Method & Linear range (ppb) & LOD (ppb) & References \\
\hline MgO-Nafion/GCE & DP-ASV, ABS pH = 5.0 & $\begin{array}{l}\mathrm{Cd}(\mathrm{II}): 1.1-23.6 \\
\mathrm{~Pb}(\mathrm{II}): 2.1-414\end{array}$ & - & {$[22]$} \\
\hline BiNPs/GCE & DP-ASV, ABS pH $=4.5$ & $5.0-60.0$ & $\mathrm{Cd}(\mathrm{II}): 0.4 ; \mathrm{Pb}(\mathrm{II}): 0.8$ & {$[25]$} \\
\hline AuNPs/GCE & DP-ASV, ABS pH = 5.0 & - & $\mathrm{Cd}(\mathrm{II}): 20.7 ; \mathrm{Pb}(\mathrm{II}): 11.2$ & {$[26]$} \\
\hline Padpa/Ru/GCE & DP-ASV, HCl 0,1 M & - & $\mathrm{Cd}(\mathrm{II}): 21.7 ; \mathrm{Pb}(\mathrm{II}): 9.8$ & {$[27]$} \\
\hline Diatomite-MPTMS/GCE & DP-ASV; ABS; $\mathrm{pH}=4.5$ & $\begin{array}{l}\mathrm{Cd}(\mathrm{II}): 20-300 \\
\mathrm{~Pb}(\mathrm{II}): 20-150\end{array}$ & $\mathrm{Cd}(\mathrm{II}): 15.9 ; \mathrm{Pb}(\mathrm{II}): 6.9$ & This work \\
\hline
\end{tabular}

Glassy carbon electrode (GCE); bismuth nanoparticles (BiNPs); gold nanoparticles (AuNPs); tris(2,2' -bipyridyl)Ru(II) (Padpa/Ru).

seen in Table 4, the GCE modified with MPTMS-diatomite developed in the present work shows good LOD compared with other similar materials/GCE reported previously in the literature [21-24]. This indicates that MPTMS-diatomite is a potential material for electrode modifiers.

\section{Conclusions}

The effects of functionalization conditions on the loading of MPTMS in diatomite were investigated. Diatomite from Phu Yen consists of mainly amorphous structure. The crystallization to form quartz occurs at more than $300^{\circ} \mathrm{C}$. The diatomite with thermal treatment in the range of $100-300^{\circ} \mathrm{C}$ is favorable for functionalization. The humidity of diatomite also affects the functionalization level significantly. The MPTMS loading around $9.8 \%$ peaked as diatomite was hydrated for 3 hours.
We have demonstrated that MPTMS-diatomite is useful to prepare chemically modified glassy carbon electrodes. The electrode modified by MPTMS-diatomite exhibited potential for the use of the simultaneous determination of cadmium and lead by DP-ASV. The stripping peak currents of the two metal ions had linear relationships with the concentrations in the range of 20 to $300 \mathrm{ppb}(i(\mu \mathrm{A})=-0.0202+0.0036 \mathrm{C}(\mathrm{ppb})$, $\left.R^{2}=0.9997\right)$ for $\mathrm{Cd}(\mathrm{II})$ and 20 to $150 \mathrm{ppb}(i(\mu \mathrm{A})=-0.1179+$ $0.0069 C$ (ppb), $\left.R^{2}=0.9943\right)$ for $\mathrm{Pb}(\mathrm{II})$. The LOD for Cd(II) and $\mathrm{Pb}$ (II) calculated was $15.9 \mathrm{ppb}$ and $6.9 \mathrm{ppb}$.

\section{Conflicts of Interest}

The authors declare that there are no conflicts of interest regarding the publication of this paper. 


\section{References}

[1] L. Cui, Y. Wang, L. Gao et al., "EDTA functionalized magnetic graphene oxide for removal of $\mathrm{Pb}$ (II), $\mathrm{Hg}$ (II) and $\mathrm{Cu}(\mathrm{II})$ in water treatment: adsorption mechanism and separation property," Chemical Engineering Journal, vol. 281, pp. 1-10, 2015.

[2] F. A. Aydin and M. Soylak, "Separation, preconcentration and inductively coupled plasma-mass spectrometric (ICP-MS) determination of thorium(IV), titanium(IV), iron(III), lead(II) and chromium(III) on 2-nitroso-1-naphthol impregnated MCI GEL CHP20P resin," Journal of Hazardous Materials, vol. 173, no. 1-3, pp. 669-674, 2010.

[3] J. Otero-Romaní, A. Moreda-Piñeiro, P. Bermejo-Barrera, and A. Martin-Esteban, "Inductively coupled plasma-optical emission spectrometry/mass spectrometry for the determination of $\mathrm{Cu}, \mathrm{Ni}, \mathrm{Pb}$ and $\mathrm{Zn}$ in seawater after ionic imprinted polymer based solid phase extraction," Talanta, vol. 79, no. 3, pp. 723729, 2009.

[4] K. Ndung'u, S. Hibdon, and A. R. Flegal, "Determination of lead in vinegar by ICP-MS and GFAAS: evaluation of different sample preparation procedures," Talanta, vol. 64, no. 1, pp. 258263, 2004.

[5] A. Maghear, M. Etienne, M. Tertiş, R. Sandulescu, and A. Walcarius, "Clay-mesoporous silica composite films generated by electro-assisted self-assembly," Electrochimica Acta, vol. 112, pp. 333-341, 2013.

[6] M. M. Abdel-Galeil, M. M. Ghoneim, H. S. El-Desoky, T. Hattori, and A. Matsuda, "Anodic stripping voltammetry determination of lead ions using highly sensitive modified electrodes based on multi-walled carbon nanotube," Journal of Chemistry and Biochemistry, vol. 2, no. 2, 2014.

[7] P. Zhang, S. Dong, G. Gu, and T. Huang, "Simultaneous determination of $\mathrm{Cd}^{2+}, \mathrm{Pb}^{2+}, \mathrm{Cu}^{2+}$ and $\mathrm{Hg}^{2+}$ at a carbon paste electrode modified with ionic liquid-functionalized ordered mesoporous silica," Bulletin of the Korean Chemical Society, vol. 31, no. 10, pp. 2949-2954, 2010.

[8] A. Sánchez, S. Morante-Zarcero, D. Pérez-Quintanilla, I. Sierra, and I. Del Hierro, "Determination of $\mathrm{Hg}$ (II) in natural waters using a carbon paste electrode modified with hybrid mesostructured silica nanoparticles," Sensors and Actuators, B: Chemical, vol. 163, no. 1, pp. 38-43, 2012.

[9] P. Kula, Z. Navrátilová, P. Kulová, and M. Kotoucek, "Sorption and determination of $\mathrm{Hg}$ (II) on clay modified carbon paste electrodes," Analytica Chimica Acta, vol. 385, no. 1-3, pp. 91-101, 1999.

[10] Z. Navrátilová and P. Kula, "Clay modified electrodes: present applications and prospects," Electroanalysis, vol. 15, no. 10, pp. 837-846, 2003.

[11] Y. Al-Degs, M. A. M. Khraisheh, and M. F. Tutunji, "Sorption of lead ions on diatomite and manganese oxides modified diatomite," Water Research, vol. 35, no. 15, pp. 3724-3728, 2001.

[12] M. A. Al-Ghouti, M. A. M. Khraisheh, S. J. Allen, and M. N. Ahmad, "The removal of dyes from textile wastewater: a study of the physical characteristics and adsorption mechanisms of diatomaceous earth," Journal of Environmental Management, vol. 69, no. 3, pp. 229-238, 2003.

[13] J. Zhang, T. Ding, Z. Zhang, L. Xu, and C. Zhang, "Enhanced adsorption of trivalent arsenic from water by functionalized diatom silica shells," PLoS ONE, vol. 10, no. 4, Article ID e0123395, 2015.

[14] Y. Yu, J. Addai-Mensah, and D. Losic, "Functionalized diatom silica microparticles for removal of mercury ions," Science and
Technology of Advanced Materials, vol. 13, no. 1, Article ID 015008, 2012.

[15] I. K. Tonlé, E. Ngameni, H. L. Tcheumi, V. Tchiéda, C. Carteret, and A. Walcarius, "Sorption of methylene blue on an organoclay bearing thiol groups and application to electrochemical sensing of the dye," Talanta, vol. 74, no. 4, pp. 489-497, 2008.

[16] T. Zhang, L. Zeng, L. Han et al., "Ultrasensitive electrochemical sensor for p-nitrophenyl organophosphates based on ordered mesoporous carbons at low potential without deoxygenization," Analytica Chimica Acta, vol. 822, pp. 23-29, 2014.

[17] G. Rytwo, D. Tropp, and C. Serban, "Adsorption of diquat, paraquat and methyl green on sepiolite: experimental results and model calculations," Applied Clay Science, vol. 20, no. 6, pp. 273-282, 2002.

[18] R. A. Shawabkeh and M. F. Tutunji, "Experimental study and modeling of basic dye sorption by diatomaceous clay," Applied Clay Science, vol. 24, no. 1-2, pp. 111-120, 2003.

[19] M. A. M. Khraisheh, M. A. Al-Ghouti, S. J. Allen, and M. N. Ahmad, "Effect of $\mathrm{OH}$ and silanol groups in the removal of dyes from aqueous solution using diatomite," Water Research, vol. 39, no. 5, pp. 922-932, 2005.

[20] P. Yuan, D. Q. Wu, H. P. He, and Z. Y. Lin, “The hydroxyl species and acid sites on diatomite surface: a combined IR and Raman study," Applied Surface Science, vol. 227, no. 1-4, pp. 30-39, 2004.

[21] U. Johansson, A. Holmgren, W. Forsling, and R. L. Frost, "Adsorption of silane coupling agents onto kaolinite surfaces," Clay Minerals, vol. 34, no. 2, pp. 239-246, 1999.

[22] Z. Wu, C. Xu, H. Chen et al., "Mesoporous $\mathrm{MgO}$ nanosheets: 1,6-hexanediamin-assisted synthesis and their applications on electrochemical detection of toxic metal ions," Journal of Physics and Chemistry of Solids, vol. 74, no. 7, pp. 1032-1038, 2013.

[23] C. Hu, K. Wu, X. Dai, and S. Hu, "Simultaneous determination of lead(II) and cadmium(II) at a diacetyldioxime modified carbon paste electrode by differential pulse stripping voltammetry," Talanta, vol. 60, no. 1, pp. 17-24, 2003.

[24] S. Ramezani, M. Ghobadi, and B. N. Bideh, "Voltammetric monitoring of $\mathrm{Cd}$ (II) by nano- $\mathrm{TiO}_{2}$ modified carbon paste electrode sensitized using 1,2-bis-[o-aminophenyl thio] ethane as a new ion receptor," Sensors and Actuators, B: Chemical, vol. 192, pp. 648-657, 2014.

[25] D. Yang, L. Wang, Z. Chen, M. Megharaj, and R. Naidu, "Anodic stripping voltammetric determination of traces of $\mathrm{Pb}$ (II) and Cd(II) using a glassy carbon electrode modified with bismuth nanoparticles," Microchimica Acta, vol. 181, no. 11-12, pp. 11991206, 2014.

[26] X. Xu, G. Duan, Y. Li et al., "Fabrication of gold nanoparticles by laser ablation in liquid and their application for simultaneous electrochemical detection of $\mathrm{Cd}^{2+}, \mathrm{Pb}^{2+}, \mathrm{Cu}^{2+}, \mathrm{Hg}^{2+}$, ACS Applied Materials and Interfaces, vol. 6, no. 1, pp. 65-71, 2014.

[27] E. A. Khudaish, M. M. Al-Hinaai, and S. H. Al-Harthi, "A solidstate sensor based on tris(2,2I-bipyridyl)ruthenium(II)/poly(4aminodiphenylamine) modified electrode: characterization and applications," Sensors and Actuators, B: Chemical, vol. 185, pp. 478-487, 2013. 

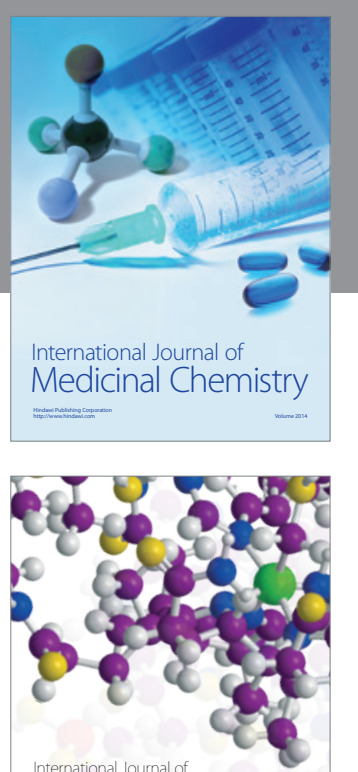

Carbohydrate Chemistry

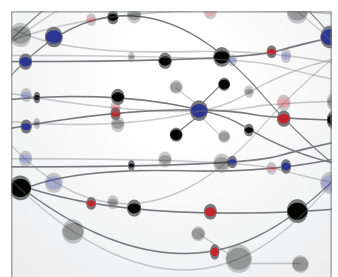

The Scientific World Journal
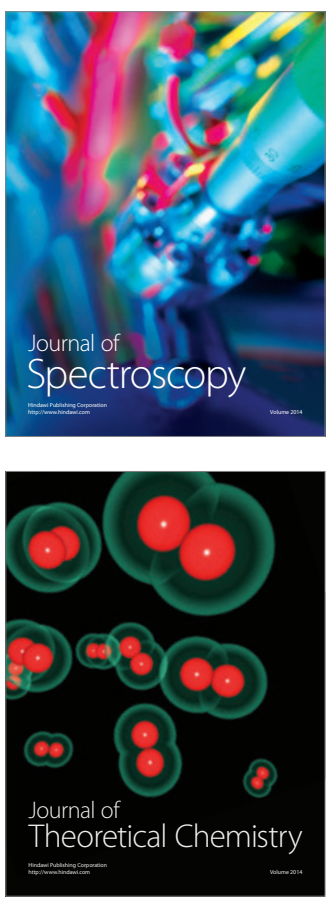
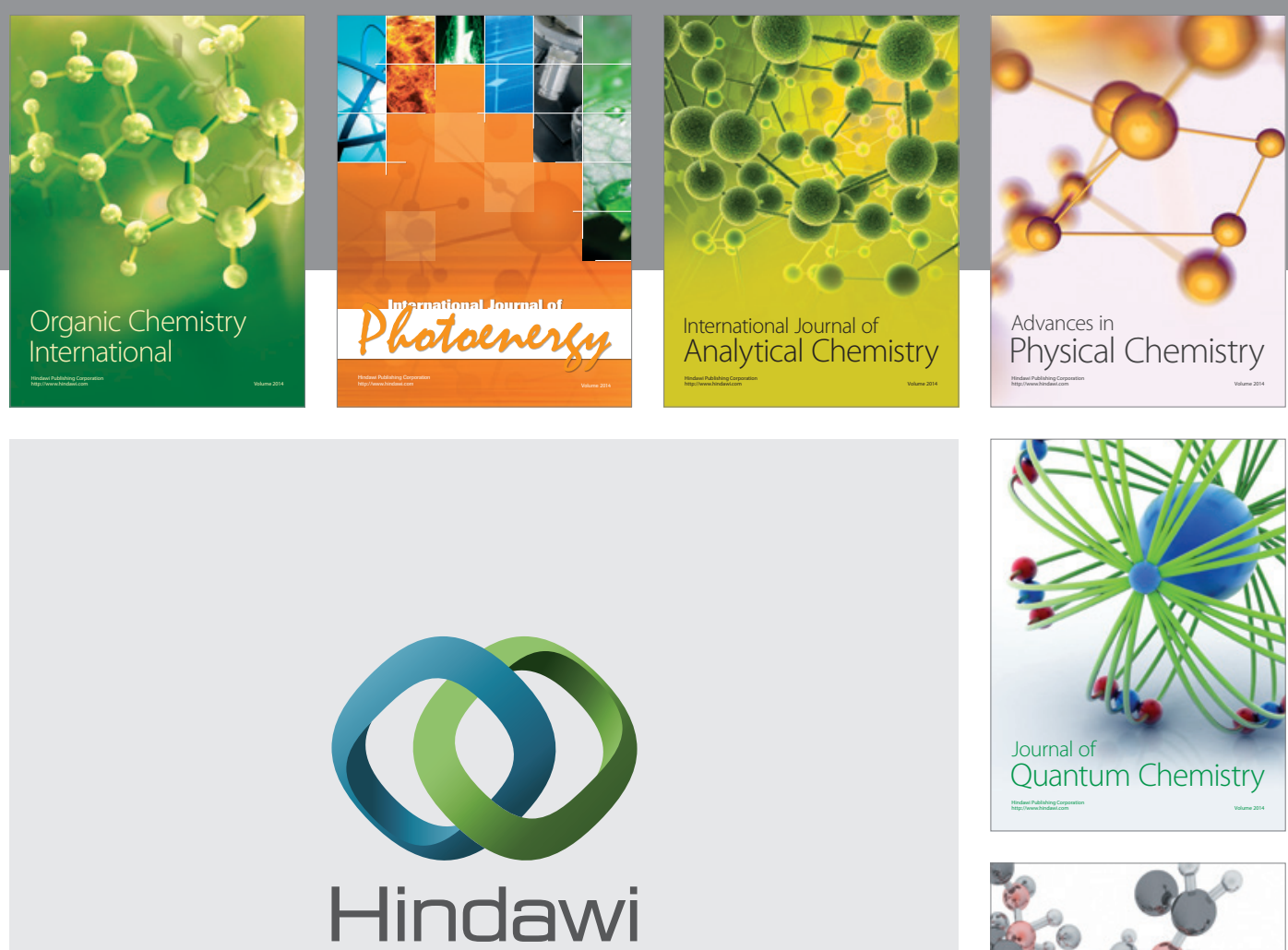

Submit your manuscripts at

https://www.hindawi.com

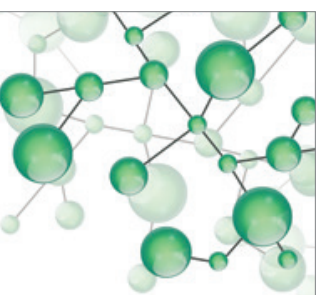

International Journal of

Inorganic Chemistry
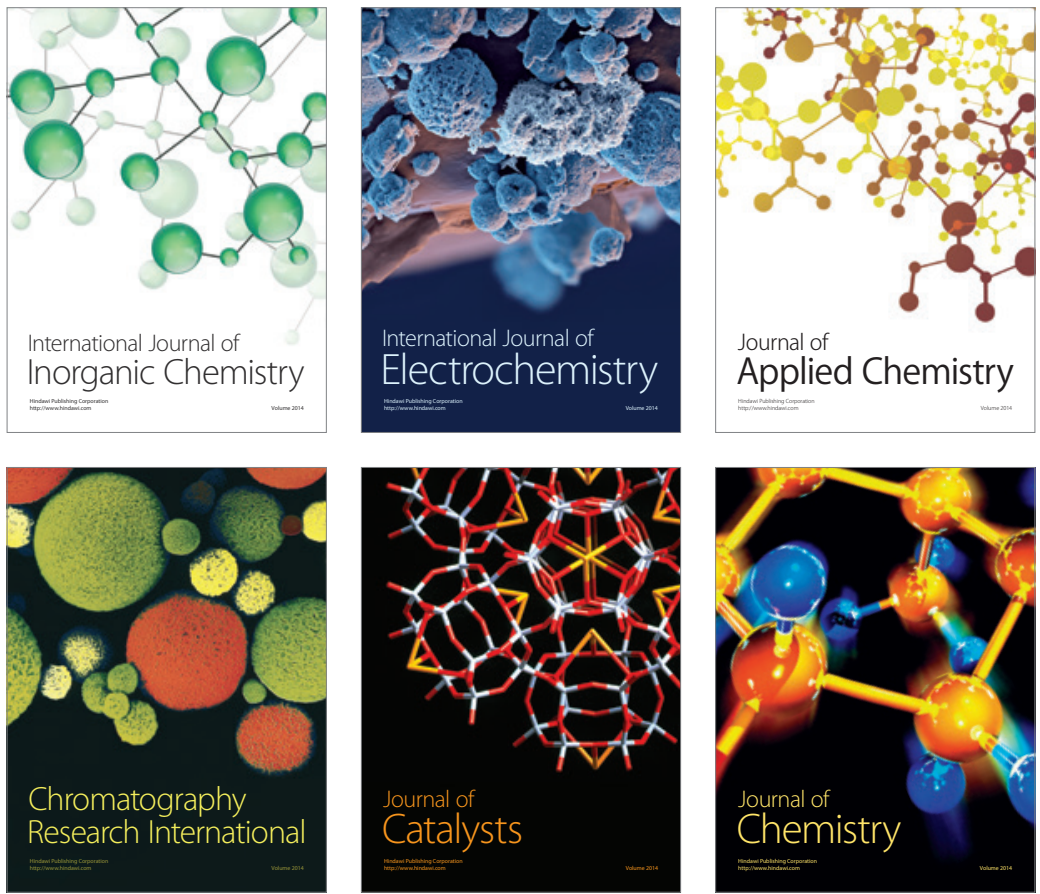

Journal of

Applied Chemistry
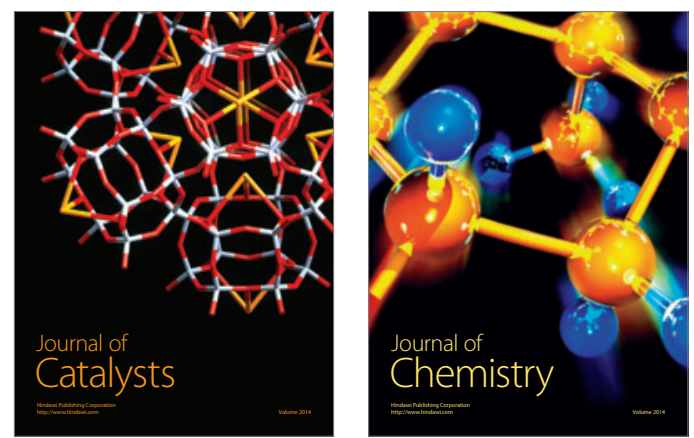
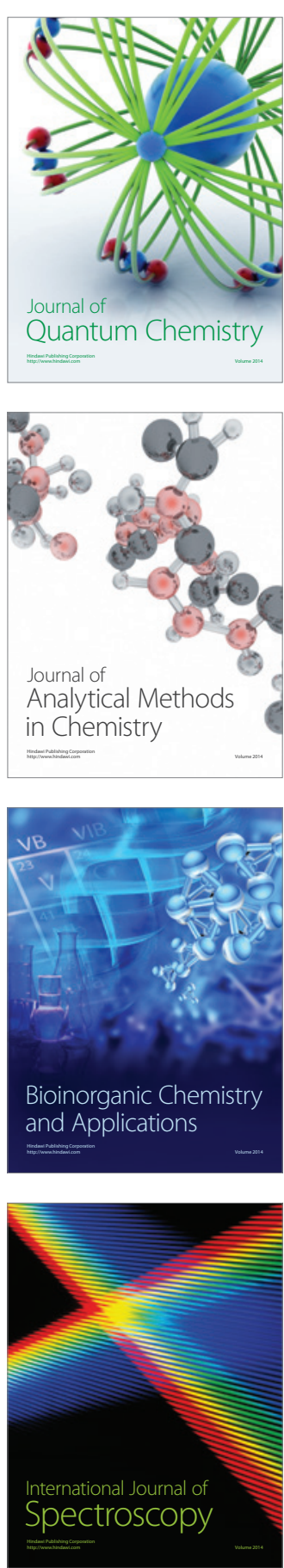